\title{
Pengaruh Pemberian Ampas Tahu sebagai Campuran Pakan terhadap Pertumbuhan Cacing Tanah Pheretima sp
}

\section{The Effect of Providing Tofu Waste as Feed Additive on Growth of Earthworm Pheretima sp}

\author{
B. Brata, A. Juliansyah, dan B. Zain \\ Jurusan Peternakan Fakultas Pertanian Universitas Bengkulu \\ Jl. WR. Supratman Kel. Kandang Limun Kec. Muara Bangkahulu Kota Bengkulu \\ e-mail: Ariefjuliansyah94@gmail.com
}

\begin{abstract}
This study aimed to determine the effect of tofu waste as a feed mixture to the growth of earthworm Pheretima $s p$. This research was conducted in Bengkulu City and Animal Husbandry Laboratory of Bengkulu University. This research used method of Completely Randomized Design with 4 treatments and 5 replicates: $(\mathrm{P} 1)=$ Rice husk 50\% + Feces of cow 50\% + (0\% tofu waste), (P2) = Rice husk 50\% + Cow feces $45 \%+(5 \%$ tofu waste), $(\mathrm{P} 3)=$ Rice husk $50 \%+$ Cow feces $40 \%+(10 \%$ tofu waste $),(\mathrm{P} 4)=$ Rice husk $50 \%+$ Cow feces $35 \%+(15 \%$ tofu waste). The result of this research showed that the feeding of mixed ration with the stofu waste worm in Pheretima $s p$ was very significant $(\mathrm{P}<0.01)$ to the growth of Pheretima $s p$ earthworm weight and significantly affected $(\mathrm{P}<0.01)$ on the offsprings weight on each maintenance unit, and was significantly different $(\mathrm{P}<0.05)$ on the average of offsprings body weight per head.
\end{abstract}

Key words: tofu waste, mixture of feed, growth, earthworm Pheretima sp.

\begin{abstract}
ABSTRAK
Penelitian ini bertujuan untuk mengetahui pengaruh pemberian ampas tahu sebagai campuran pakan terhadap pertumbuhan cacing tanah Pheretima sp. Lokasi penelitian ini dilaksanakan di Kota Bengkulu dan Laboratorium Peternakan Universitas Bengkulu. Penelitian ini menggunakan metotede Rancangan Acak Lengakap (RAL) dengan 4 perlakauan serta 5 ulangan: $(\mathrm{P} 1)=$ Sekam padi $50 \%+$ Feses sapi 50\% $+(0 \%$ ampas tahu $),(\mathrm{P} 2)=$ Sekam padi $50 \%+$ Feses sapi $45 \%+(5 \%$ ampastahu $),(\mathrm{P} 3)=$ Sekam padi $50 \%+$ Feses sapi $40 \%+(10 \%$ ampas tahu), $(\mathrm{P} 4)=$ Sekam padi $50 \%+$ Feses sapi $35 \%+(15 \%$ ampas tahu $)$. Hasil dari penelitian ini menunjukan bahwa pemberian pakan campuran ampas tahu pada media cacing tanah Pheretima sp berpengaruh sangat nyata $(\mathrm{P}<0,01)$ terhap pertumbuhan bobot induk cacing tanah Pheretima $s p$ dan berpengaruh sangat nyata $(\mathrm{P}<0,01)$ terhadap bobot badan anak per unit pemeliharaan serta berbeda nyata $(\mathrm{P}<0,05)$ terhadap rataan bobot badan anak per ekor.
\end{abstract}

Kata kunci: ampas tahu, campuran pakan, pertumbuhan, cacing tanah Pheretima sp.

\section{PENDAHULUAN}

Cacing tanah adalah salah satu jenis fauna Indonesia dan termasuk kedalam kelompok hewan tingkat rendah, yang tidak bertulang belakang (invertebrata) yang merupakan kelompok annelid atau cacing bersegmen dimana hewan ini ditemukan pada lingkungan terrestrial basah di Indonesia. Menurut pendapat Catalan (1981) bahwa di dunia ini terdapat kira-kira
1800 spesies cacing tanah yang telah diidentifikasi dan diklasifikasikan.

Ada beberapa jenis cacing tanah yang banyak dikembangkan serta dimanfaatkan oleh manusia yaitu, berasal dari famili Lumricidae, Megascolecidae, Acanthorodrilidae, dan Octochaetidae dengan genus Lumbricus, Eisenia, Pheretima, Perionyx, Diplocardi dan Lidrillus. Menurut Rukmana (1999) menyatakan bahwa dari beberapa jenis 
cacing tanah yang ada, hanya 4 yang dibudidayakan dan diproduksi secara komersial diantaranya Rumbricus rubellus, Eisenia foetida, Pheretima, dan Eudrilus eugeuniae.

Cacing tanah dapat hidup dengan optimal apabila hidup pada media sesuai dengan kebutuhannya. Menurut Aziz, (2015) syarat hidup cacing tanah dipengaruhi oleh beberapa faktor diantaranya kelembapan, suhu, ketersediaan zat organik, keasaman (pH). Puspitasari (1995) menyatakan, pH optimum untuk pertumbuhan dan perkembangbiakan cacing tanah berkisar antara 6,8-7,2 sedangkan suhu optimum pemeliharaan yaitu 23-260C. Serta kelembaban yang dibutuhkan untuk pertumbuhan dan perkembangbiakan cacing tanah yaitu 28-42\% (Minnich, 1977). Dampak ketidak seimbangan dari faktor tersebut dapat mengakibatkan pertumbuhan cacing terhambat dan bahkan menyebabkan kematian. Pada umumnya cacing tanah hidup pada jenis bahan organik yang berasal dari pupuk kandang dan sisa-sisa tumbuhan (Rukmana, 1999).

\section{Menurut Gaddie dan Douglas} (1977), kotoran hewan merupakan habitat utama cacing tanah dan hampir secara keseluruhan sesuai (cocok), baik sebagai bahan pakan maupun sebagai media, seperti feses sapi. Aziz (2015) mengemukakan bahwa feses sapi memiliki banyak zat organik sehingga bagus untuk pertumbuhan cacing. Terdapat kendala apabila feses sapi langsung dipakai tanpa melewati proses pengeringan. Selain kotoran hewan, limbah industri dan pertanian seperti serbuk gergaji, serutan, kayu, kompos sampah, dedak, jerami, rumput dan daun daunan dapat dimanfaatkan sebagai bahan pembuatan sarang budidaya cacing tanah.

Seperti halnya pada hewan lain, cacing tanah juga memerlukan makanan untuk melanjutkan hidup dan perkembangbiakannya. Pemberian pakan cacing tanah selain didapat dari medianya sendiri, pakan juga bisa diberikan dengan cara memberikan pakan tambahan. Ada beberapa pakan yang bisa diberikan kepada cacing sebagai pakan tambahan seperti, sayur - sayuran, daun lamtoro, dedak padi, dedak jagung, ampas singkong, ampas tahu, dan batang pisang. Menurut Catalan (1981) Karena cacing tidak mempunyai gigi dan membutuhkan air yang cukup banyak, maka pakan yang diberikan semestinya diberikan dalam bentuk bubur dengan perbandingan $25 \%$ padatan dan $75 \%$ air yang ditabur pada permukaan media dan jumlah pakan yang diberikan sama dengan bobot cacing tanah yang ada. Pada dasarnya dalam pemberian pakan cacing tanah tidak berbeda dengan jenis ternak lainnya. Beberapa jenis pakan harus mengandung protein, lemak, karbohidrat, vitamin, mineral dan zat-zat makanan lainnya yang mudah dicerna oleh cacing tanah sehingga sangat bermanfaat untuk pertumbuhan dan kesehatannya.

Menurut Wiriano (1985) ampas tahu merupakan limbah dalam bentuk padatan dari bubur kedelai yang diperas dan tidak berguna lagi dalam pembuatan tahu dan cukup potensial dipakai sebagai bahan makanan ternak cacing, karena ampas tahu masih mengandung gizi yang baik dan dapat digunakan sebagai ransum ternak 
besar dan kecil. Ampas tahu diperkirakan dapat menjadi alternatif sebagai bahan pakan budidaya cacing tanah. Menurut Mursining (2006) kandungan gizi dalam ampas tahu adalah protein $21,23 \%$, lemak $16,22 \%$, karbohidrat $19 \%$, serat kasar 29,59\%, kadar abu 5,45\%, dan air 9,84\%.

Berhubungan dengan hal-hal tersebut diatas melalui penelitian ini diharapkan dapat diperoleh informasi mengenai, pengaruh pemberian ampas tahu sebagai campuran pakan cacing tanah Pheretima $s p$ terhadap pertumbuhannya. Tujuan penelitian ini untuk menguji pengaruh pemberian ampas tahu sebagai campuran pakan terhadap pertumbuhan cacing tanah Pheretima $s p$.

\section{MATERI DAN METODE}

Penelitian ini dilaksanakan selama 3 bulan Kota Bengkulu dan dilaboratorium Peternakan Universitas Bengkulu.

Alat yang digunakan dalam penelitian ini, yaitu 20 buah ember plastik dengan volume1,5 liter, timbangan analitik dengan kapasitas 310 gram, termometer media, soiltester, karung plastik, cangkul, sarung tangan, botol semprot, kamera dan alat tulis.

Bahan - bahan yang digunakan adalah 200 ekor cacing Pheretima $s p$ umur 2-3 hari, feses sapi, sekampadi, ampastahu, kapur tembok dan air.

\section{Tahapan Penelitian}

Tahapan penelitian yang dilakukan pada penelitian ini terdiri atas beberapa tahapan yaitu: persiapan ruangan penelitian, pengadaan cacing tanah Pheretima $s p$, persiapan media tumbuh, persiapan ampas tahu sebagai pakan campuran, persiapan penelitian serta pemeliharaan cacing tanah Pheretima sp.

\section{Persiapan Ruangan Penelitian}

Sebelum mulainya pelaksanaan penelitian tahap pertama yakni dengan memebersihkan ruangan penelitian serta menyiapakan rak (kandang cacing) dengan 4 tingkatan, yang nantinya digunakan untuk meletakkan ember yang sudah diisi dengan bibit cacing.

\section{Pengadaan Cacing Tanah Pheretima sp}

Pengadakan bibit cacing tanah Pheretima sp, dengan melakukan pemeliharaan cacing tanah Pheretima $s p$ yang berumur dewasa sampai menghasilkan anak. Kemudian anakan yang berumur 2 3 hari akan diambil sebanyak 200 ekor untuk digunakan sebagai bahan penelitian. Untuk mengetahui umur cacing tanah berumur $2-3$ hari biasanya cacing tanah bergerombol di sekitar kokon.

\section{Persiapan Media Tumbuh}

Media yang digunakan dalam penelitian ini yaitu, feses sapi dan sekam padi. Dalam persiapan media, sebelum mencampurkan feses sapi dengan sekam padi, feses sapi terlebih dahulu dilakukan penyisiran serta pengeringanginan dengan tujuan agar menghilangkan benda - benda anorganik yang terdapat pada feses sapi. Kemudian baru dilakukannya pencampuran feses dengan sekam padi sebagai media, dalam melakukan pencampuran media, 
perlu menambahkan kapur sebanyak 0,2\% dan air secukupnya dengan kadar air kira kira mencapai 60\% (Brata, 2003), kemudian melakukan fermentasi media dengan menggunakan kantong plastik, selama 21 hari dengan tujuan untuk menghilangkan gas - gas yang terdapat pada media seperti gas methan (Waluyo, 1993). Sebelum media dilakukan dalam pemeliharaan cacing tanah, media perlu dilakukan uji N. Perhitungan kebutuhan media cacing tanah menggunakan rumus menurut Brata (2003), Y= a x b x 3 .

Keterangan :

$\mathrm{a}=$ Bobot badan dewasa cacing tanah

$\mathrm{b}=$ Lama pemeliharaan

3 = Bobot badan cacing tanah dihitung sebanyak tiga kali

Tabel 1. Kandungan Nitrogen Media

\begin{tabular}{cc}
\hline Perlakuan & $\begin{array}{c}\text { Kandungan N } \\
(\%)\end{array}$ \\
\hline P1 & 3,0 \\
P2 & 3,4 \\
P3 & 3,6 \\
P4 & 4,0
\end{tabular}

Sumber : Analisis Laboratorium Jurusan Peternakan Fakultas Pertanian Universitas Bengkulu (2017).

Perlakuan adalah:

$\mathrm{P} 1=$ Sekam padi $50 \%+$ feses sapi $50 \%+$ (0\% ampas tahu).

$\mathrm{P} 2=$ Sekam padi $50 \%+$ feses sapi $45 \%+$ (5\% ampas tahu).

$\mathrm{P} 3=$ Sekam padi $50 \%+$ feses sapi $40 \%+$ (10\% ampas tahu).

$\mathrm{P} 4=$ Sekam padi $50 \%+$ feses sapi $35 \%+$ (15\% ampas tahu).

\section{Persiapan Pakan}

Dalam penelitian ini digunakan pakan tambahan berupa ampas tahu yang diperoleh dari industri pembuatan tahu di daerah Provinsi Bengkulu tepatnya di Kelurahan Bentiring Permai. Penambahan pakan ampas tahu diberikan setiap 10 hari sekali selama pemeliharaan 2 bulan. Ampas tahu sebelum diberikan keperlakuan harus di kurangi kadar airnya dengan cara penganginan selama kurang lebih tiga hari.

\section{Persiapan Penelitian dan Pemeliharaan Cacing Tanah}

Pada pemeliharaan cacing, dari setiap ember yang telah diisi dengan media, kemudian akan dimasukan 10 ekor anak cacing tanah Pheretima $s p$ yang berumur 23 hari dengan cara membuat lubang pada tengah-tengah media dengan kedalaman berkisar $5 \mathrm{~cm}$ selanjutnya lubang ditutup. Untuk tempat pemeliharaan cacing ditutup dengan menggunakan kain atau plastik dan memberi kode pada setiap ember. Penyiraman media cacing dilakukan sekali dalam 3 hari kemudian mengembalikan media 10 hari sekali (Brata, 2003).

\section{Rancangan Penelitian}

Penelitian ini menggunakan rancangan acak lengkap (RAL) dengan 4 perlakuan dan 5 ulangan. Setiap perlakuan menggunakan feses sapi dan sekam padi serta ampas tahu dengan jumlah imbangan ampas tahu yang diberikan setiap perlakuan berbeda. Setiap ulangan ditanami 10 ekor bibit cacing tanah Pheretima sp umur 2-3 hari. Cacing yang digunakan dalam penelitian ini sebanyak 200 ekor dengan 
perlakuan yang terbagi kedalam 5 perlakuan.

\section{Variabel yang Diamati}

Variabel yang diamati adalah pertambahan bobot badan induk, bobot badan anak, bobot badan anak per ekor serta mortalitas.

\section{Pertambahan Bobot Badan Induk} Cacing Tanah Pheretima sp. per Unit Pemeliharaan

Bobot badan induk dihitung dan dilakukan penimbangan pada awal dan akhir pemeliharaaan. Dalam melakukan penghitungan dan penimbangan $\mathrm{PBB}$ induk seluruh induk terlebih dahulu harus dibersihkan dari kotoran media dan di masukkan kedalam kantong plastik kemudian baru dilakukan penimbangan. Selanjutnya hasil penimbangan dikurangi dengan berat plastik.

Pada pengukuran pertambahan bobot badan induk dapat dihitung dengan menggunakan rumus : PBB induk = bobot badan akhir - bobot badan awal.

\section{Bobot Badan Anak Cacing Tanah Pheretima sp. per Unit Pemeliharaan}

Untuk pengamatan pada bobot badan anak dilakukan hanya dua kali selama penelitian ini, yaitu pengukuran dilakukan pada akhir penelitian. Dalam menghitung bobot badan anak cacing tanah Pheretima $s p$ dapat dihitung dengan cara menimbang bobot badan anak per unit pemeliharaan.

\section{Bobot Badan Anak Cacing Tanah Pheretima sp. per Ekor}

Perhitungan bobot badan anak cacing tanah Pheretima sp dapat dihitung dengan menggunakan rumus sebagai berikut :

Bobot badan anak $/$ ekor $=\frac{\text { Total bobot badan anak }}{\text { Total jumlah anak per unit pemeliharaan }}$

\section{Mortalitas Induk Cacing Tanah}

Pheretima sp. per Unit Pemeliharaan

Perhitungan mortalitas induk dilakukan dengan menghitung jumlah kematian induk cacing dari keseluruhan unit pemeliharaan. Perhitungan hanya dilakukan satu kali di akhir penelitian.

\section{Analisis data}

Semua data yang diperoleh dianalisis secara stastistik dengan menggunakan analisis varians. Apabila ada perbedaan nyata maka akan dilanjutkan dengan Uji Jarak Berganda Duncan's (Duncan's Multiple Range test/DMRT) untuk mengetahui perbedaan antara empat perlakuan (Yitnosumarto,1993).

\section{HASIL DAN PEMBAHASAN}

\section{Pertambahan Bobot Badan Induk Cacing Tanah Pheretima sp}

Hasil rataan pertambahan bobot badan induk cacing tanah Pheretima $s p$ dengan pelakuan pertama $\mathrm{P} 1=50 \%$ sekam padi $+50 \%$ feses sapi, $\mathrm{P} 2=50 \%$ sekam padi $+45 \%$ feses sapi $+5 \%$ ampas tahu, $\mathrm{P} 3=$ $50 \%$ sekam padi $+40 \%$ feses sapi $+10 \%$ ampas tahu dan $\mathrm{P} 4=50 \%$ sekam padi + $35 \%$ feses sapi $+15 \%$ ampas tahu ditampilkan pada Tabel 2 dibawah ini. 
Tabel 2. Rataan pertambahan bobot badan induk cacing tanah Pheretima sp (gr) selama 60 hari pemeliharaan

\begin{tabular}{ccccccc}
\hline \multirow{2}{*}{ Perlakuan } & \multicolumn{5}{c}{ Ulangan } & \multirow{2}{*}{ Rataan } \\
\cline { 2 - 5 } & 1 & 2 & 3 & 4 & 5 & \\
\hline P1 & 1.1 & 1.21 & 1.23 & 1.22 & 1.23 & $1.198^{\mathrm{d}}$ \\
P2 & 1.32 & 1.32 & 1.31 & 1.33 & 1.24 & $1.304^{\mathrm{c}}$ \\
P3 & 1.53 & 1.49 & 1.43 & 1.58 & 1.50 & $1.506^{\mathrm{b}}$ \\
P4 & 1.66 & 1.59 & 1.56 & 1.67 & 1.65 & $1.626^{\mathrm{a}}$ \\
\hline
\end{tabular}

Keterangan: Superskrip yang berbeda menunjukkan berbeda sangat nyata $(\mathrm{P}<0,01)$

$$
\begin{aligned}
& \text { P1 }=\text { sekam padi } 50 \%+\text { feses sapi } 50 \%+(0 \% \text { ampas tahu }) . \\
& \text { P2 }=\text { sekam padi } 50 \%+\text { feses sapi } 45 \%+(5 \% \text { ampas tahu }) . \\
& \text { P3 }=\text { sekam padi } 50 \%+\text { feses sapi } 40 \%+(10 \% \text { ampas tahu }) . \\
& \text { P4 }=\text { sekam padi } 50 \%+\text { feses sapi } 35 \%+(15 \% \text { ampas tahu }) .
\end{aligned}
$$

Berdasarkan hasil dari analisis sidik ragam menunjukan bahwa pemberian pakan campuran menggunakan ampas tahu berbeda sangat nyata $(\mathrm{P}<0,01)$ terhadap bobot badan induk selama 60 hari pemeliharaan. Dapat dilihat dari data Tabel 2 rataan pertambahan bobot badan induk cacing tanah Pheretima sp, dengan masing masing perlakuan di dapat, $\mathrm{P} 1 ; 1.198 \mathrm{~g} / \mathrm{unit}$, P2; 1.304 g/unit, P3; 1.506 g/unit, dan P4; 1.626 g/unit. Adanya perbedaan dari pertambahan bobot badan induk ini karena level pemberian pakan ampas tahu pada setiap perlakuan berbeda. Selain itu pertambahan bobot badan induk cacing juga dipengaruhi oleh unsur nitrogen $(\mathrm{N})$ yang terkandung pada setiap media pemeliharaan. Hasil analisis uji $\mathrm{N}$ pada media yang di peroleh pada setiap media diantaraanya, $\mathrm{P} 1$; $3,0 \%, \mathrm{P} 2 ; 3,4 \%, \mathrm{P} 3 ; 3,6 \%$, dan P4; 4,0\%.

Berdasarkan uji lanjut Ducan Multiple Range Test (DMRT) memperlihatkan bahwa pada perlakuan P1; $1,198 \mathrm{~g} / \mathrm{unit}$ berbeda nyata $(\mathrm{P}<0,01)$ terhadap perlakuan $\mathrm{P} 2 ; 1,304$ g/unit, $\mathrm{P} 3$; 1,506 g/unit, dan P4; 1,626 g/unit. Kemudian pada perlakuan P2; 1,304 g/unit berbeda nyata $(\mathrm{P}<0,01)$ terhadap perlakuan P3; 1,506 g/unit, dan P4; 1,626 g/unit. Selanjutnya perlakuan P3; 1,506 g/unit berbeda nyata $(\mathrm{P}<0,01)$ terhadap perlakuan P4; 1,626 g/unit.

Pertumbuhan berat badan induk cacing yang tertinggi didapat pada perlakuan P4 1,626 g/unit. Dengan imbangan media $50 \%$ sekam padi $+35 \%$ feses sapi $+15 \%$ ampas tahu. Tingginya pertambahan bobot badan induk cacing tanah dipengaruhi oleh kandungan nitrogen (N) pada media P4; 4,0\% lebih tinggi jika di bandingkan dengan perlakuan P1; 3,0\%, $\mathrm{P} 2 ; 3,4 \%, \mathrm{P} 3 ; 3,6 \%$. Menurut Haryono (2003), menyatakan bahwa kandungan nitrogen yang tinggi pada media memberikan pengaruh baik pada pertumbuhan dan reproduksi.Kemudian dengan ditambahkan $15 \%$ ampas tahu pada media cacing tanah mempunyai pengaruh yang baik bagi pertumbuhan cacing tanah karena, ampas tahu mengandung banyak protein sehingga ketersediaan nutrisi pada media tercukupi. Menurut Palungkun (1999), bobot badan cacing tanah sangat 
dipengaruhi oleh kondisi media dan ketersediaan nutrisi.

Pertumbuhan bobot badan induk terendah terdapat pada perlakuan $\mathrm{P} 1 ; 3,0 \%$ dengan imbangan $50 \%$ sekam padi $+50 \%$ feses sapi (tanpa pakan tambahan). Rendahnya pertambahan bobot badan cacing tanah karena kandungan $\mathrm{N}$ pada perlakuan P1: 3,0\% lebih rendah jika dibandingkan dengan perlakuan P2: 3,4\%, P3: 3,6 dan P4: 4,0\%. Menurut pendapat Roeslim et al. (2013), cacing tanah yang mengkonsumsi pakan kaya akan nitrogen akan mengalami pertumbuhan badan yang cepat dan menghasilkan kokon yang tinggi jika dibandingkan dengan yang mengkunsumsi pakan dengan nitrogen yang rendah.

\section{Bobot Badan Anak Cacing Tanah Pheretima sp per Unit Pemeliharaan}

Rataan bobot badan anak per unit pemeliharaan cacing tanah Pheretima $s p$ dengan perlakuan pertama $\mathrm{P} 1 ; 50 \%$ sekam padi $+50 \%$ feses sapi, $\mathrm{P} 2 ; 50 \%$ sekam padi $+45 \%$ feses sapi $+5 \%$ ampas tahu, P3; $50 \%$ sekam padi $+40 \%$ feses sapi $+5 \%$ ampas tahu, P4; 50\% sekam padi $+35 \%$ feses sapi $+15 \%$ ampas tahu seperti terlihat pada tabel 3 .

Hasil sidik ragam menunjukan bahwa dalam pemberian pakan tambahan ampas tahu dengan media sekam padi, dan feses sapi menunjukan perbedaan yang sangat nyata $(\mathrm{P}<0.01)$ terhadap bobot badan anak cacing tanah Pheretima $s p$ per unit pemeliharaan. Rataan bobot badan anak cacing tanah Pheretima $s p$ setiap perlakuan, P1; 0,298 g/unit, P2; 0,524 g/unit, P3; 0,69 g/unit, P4; 0,676 g/unit. Hal ini disebabkan karena kandungan $\mathrm{N}$ pada setiap media perlakuan berbeda. Selain dari kandungan $\mathrm{N}$ yang terkandung pada media faktor pakan juga dapat mempengaruhi bobot badan anak cacing tanah Pheretima sp.

Hasil uji lanjut Duncan Multiple Range Test (DMRT) menunjukan bahwa perlakuan P1, $0.298 \mathrm{~g} / \mathrm{unit}$ berbeda nyata $(\mathrm{P}<0,01)$ terhadap perlakuan $\mathrm{P} 2 ; 0.524$ g/unit, P3; 0,69 g/unit dan P4; 0,676 g/unit. Selanjutnya pada perlakuan P2; 0.524 g/unit berbeda nyata $(\mathrm{P}<0,01)$ terhadap perlakuan P3; 0,69 g/unit, dan P4; 0,676 g/unit. Selanjutnya pada perlakuan P3; 0,69 tidak berbeda nyata $(\mathrm{P}>0,05)$ terhadap perlakuan P4, 0,676 g/unit.

Tabel 3 . Rataan bobot badan anak cacing tanah Pheretima sp

\begin{tabular}{ccccccc}
\hline \multirow{2}{*}{ Perlakuan } & \multicolumn{5}{c}{ Ulangan $(\mathrm{g})$} & \multirow{2}{*}{ Rataan } \\
\cline { 2 - 6 } & 1 & 2 & 3 & 4 & 5 & \\
\hline P1 & 0.29 & 0.28 & 0.29 & 0.33 & 0.30 & $0.298^{\mathrm{c}}$ \\
P2 & 0.49 & 0.52 & 0.57 & 0.54 & 0.50 & $0.524^{\mathrm{b}}$ \\
P3 & 0.69 & 0.68 & 0.69 & 0.70 & 0.69 & $0.690^{\mathrm{a}}$ \\
P4 & 0.68 & 0.69 & 0.62 & 0.70 & 0.69 & $0.676^{\mathrm{a}}$ \\
\hline
\end{tabular}

Keterangan: Superskrip yang berbeda menunjukkan berbeda sangat nyata $(\mathrm{P}<0,01)$

$\mathrm{P} 1=$ sekam padi $50 \%+$ feses sapi $50 \%+(0 \%$ ampas tahu $)$

$\mathrm{P} 2=$ sekam padi $50 \%+$ feses sapi $45 \%+(5 \%$ ampas tahu $)$

$\mathrm{P} 3=$ sekam padi $50 \%+$ feses sapi $40 \%+(10 \%$ ampas tahu $)$

$\mathrm{P} 4=$ sekam padi $50 \%+$ feses sapi $35 \%+(15 \%$ ampas tahu $)$ 
Tingginya pertambahan bobot badan anak cacing tanah Pheretima sp perunit,0,69 gr selama pemeliharaan pada perlakuan P3 dengan imbangan media, sekam padi $50 \%+$ feses sapi $40 \%+10 \%$ ampas tahu dipengaruhi oleh kadar nitrogen (N) yang terkandung pada media perlakuan P3; 3,6\% lebih tinggi jika dibandingkan dengan perlakuan $\mathrm{P} 1 ; 3,0 \%$ dan $\mathrm{P} 2 ; 3,4 \%$. Dilihat dari pakan campuran yang diberikan berupa ampas tahu pada perlakuan P3 mencapai $10 \%$ dapat mempengaruhi pertambahan bobot badan anak per unit pemeliharaan. Menurut Brata (2003) menyatakan bahwa ampas tahu kaya akan zat-zat makanan dan mudah dicerna terutama pada anak cacaing tanah yang sedang dalam masa pertumbuhan.

Rendahnya pertambahan bobot badan anak cacing tanah Pheretima $s p$ per unit pada perlakuan $\mathrm{P} 1 ; 0,298$ dengan imbangan media $50 \%$ sekam padi $+50 \%$ feses sapi $+0 \%$ ampas tahu. di pengaruhi oleh faktor nitrogen pada media cacing tanah pada perlakuan $\mathrm{P} 1 ;$ 3,0 lebih rendah jika dibandikan dengan perlakuan P2; 3,4,
P3; 3,6 dan P4; 4,0. Selanjutnya pada perlakuan P1 tidak adanya penambahan pakan ampas tahu, sehingga kemungkinan cacing tanah kekurangan nutrisi yang dibutuhkan untuk pertumbuhan dan bereproduksinya. Menurut Martin et al. (1981) dalam Permata (2006), faktor-faktor yang mendukung pertumbuhan dan reproduksi cacing tanah adalah ketersediaan makanannya.

\section{Bobot Badan Anak Cacing Tanah Pheretima sp per Ekor}

Rataan bobot badan anak per ekor cacing tanah Pheretima sp selama 60 hari pemeliharaan dengan menggunakan media dari sekam padi dan feses sapi serta memanfaatkan ampas tahu sebagai pakan tambahan. Asumsi media pada perlakuan pertama P1 adalah 50\% sekam padi $+50 \%$ feses sapi, P2 $50 \%$ sekam padi $+45 \%$ feses sapi $+5 \%$ ampas tahu, P3 50\% sekam padi $+40 \%$ feses sapi $+5 \%$ ampas tahu, P4 50\% sekam padi $+35 \%$ feses sapi $+15 \%$ ampas tahu. Seperti terlihat pada tabel 4.

Tabel 4. Rataan bobot badan anak cacing tanah Pheretima sp (gr) selama 60 hari pemeliharaan

\begin{tabular}{ccccccc}
\hline \multirow{2}{*}{ Perlakuan } & \multicolumn{5}{c}{ Ulangan } & \multirow{2}{*}{ Rataan } \\
\cline { 2 - 6 } & 1 & 2 & 3 & 4 & 5 & \\
\hline P1 & 0.014 & 0.012 & 0.012 & 0.013 & 0.013 & $0.013^{\mathrm{b}}$ \\
P2 & 0.015 & 0.015 & 0.013 & 0.011 & 0.011 & $0.013^{\mathrm{b}}$ \\
P3 & 0.016 & 0.016 & 0.016 & 0.015 & 0.014 & $0.015^{\mathrm{a}}$ \\
P4 & 0.013 & 0.016 & 0.014 & 0.015 & 0.012 & $0.014^{\mathrm{ab}}$ \\
\hline
\end{tabular}

Keterangan: Superskrip yang berbeda menunjukkan berbeda nyata $(\mathrm{P}<0,05)$

$\mathrm{P} 1=$ sekam padi $50 \%+$ feses sapi $50 \%+(0 \%$ ampas tahu $)$.

$\mathrm{P} 2=$ sekam padi $50 \%+$ feses sapi $45 \%+(5 \%$ ampas tahu $)$.

$\mathrm{P} 3=$ sekam padi $50 \%+$ feses sapi $40 \%+(10 \%$ ampas tahu $)$.

$\mathrm{P} 4=$ sekam padi $50 \%+$ feses sapi $35 \%+(15 \%$ ampas tahu $)$. 
Berdasarkan dari hasil sidik ragam menunjukan bahwa dalam pemberikan pakan menggunakan ampas tahu dengan media sekam padi, dan feses sapi menunjukan perbedaan nyata $(\mathrm{P}<0.05)$ terhadap bobot badan anak cacing tanah Pheretima $S p$ per ekor. Adanya perbedaan dari bobot badan anak per ekor cacing tanah Pheretima $s p$, hal ini mungkin adanya pengaruh dari jumlah anak pada media yang berbeda pada setiap perlakuan, karena dalam menghitung berat badan anak perekor jumlah anak dibagi dengan bobot badan anak perunit pemeliharaannya. Menurut Andriyani (2006) menyatakan bahwa banyaknya jumlah anak memberikan dampak terhadap rataan bobot badan anak yang berbedasehingga mempengaruhi rataan bobot badan anak per ekornya. Selain itu Protein yang terkandung dalam media juga bisa berpengaruh terhadap bobot badan anak per ekor.

Berdasarkan uji lanjut Ducan Multiple Range Test (DMRT) memperlihatkan perlakuan P1; 0,013 g/ekor tidak berbeda nyata $(\mathrm{P}>0,05)$ terhadap perlakuan P2; 0,013 g/ekor dan P4; 0,014 g/ekor tetapi berbeda nyata $(\mathrm{P}<0,01)$ terhadap P3; 0,015 g/ekor. Kemudian pada perlakuan P2; 0,013 g/ekor tidak berbeda nyata $(\mathrm{P}>0,05)$ terhadap perlakuan $\mathrm{P} 4$; $0.014 \mathrm{~g} /$ ekor tetapi berbeda nyata $(\mathrm{P}<0,05)$ terhadap P3; 0,015 g/ekor. Pada perlakuan P3; 0.015 g/ekor tidak berbeda nyata $(\mathrm{P}>0,05)$ terhadap $\mathrm{P} 4 ; 0.014$ g/ekor.

Tingginya bobot badan anak per ekor pada perlakuan P3; 0,015 g/ekor dengan imbangan media 50\% sekam padi + $40 \%$ feses sapi $+10 \%$ ampas tahu dengan rata-rata bobot badan mencapai 0,015 g/ekor, hal ini dipengaruhi oleh terpenuhnya atau tercukupinya nutrisi yang di butuhkan oleh anak cacing tanah, karena dalam perlakuan P3 di berikannya ampas tahu $10 \%$ sebagai pakan tambahan, dan pada perlakuan P3 memiliki kandungan nitrogen $(\mathrm{N})$ yang tinggi $3,6 \%$ jika dibandingkan dengan perlakuan $\mathrm{P} 1 ; 3,0 \%$ dan $\mathrm{P} 2 ; 3,4 \%$ hal ini juga dapat memepengaruhi bobot badan anak.Sesuai menurut Palungkun (1999) bobot badan cacing tanah sangat dipengaruhi oleh kondisi media dan ketersediaan nutrisi. Selain itu faktor lingkungan juga dapat mempengaruhi pertumbuhan cacing tanah

Bobot badan anak terendah di dapat pada perlakuan P1; 0,013 g/ekor hal ini dipengaruhi oleh kurang nya nutrisi yang terkandung pada media perlakuan P1 dan juga pada perlakuan P1 tidak adanya pemberian pakan tambahan ampas tahu sehingga kebutuhan cacing kurang terpenuhi.

Dalam penghitungan bobot badan anak per ekor jemlah rata - rata setiap perlakuan tidak jauh berbeda.

\section{Mortalitas Induk Cacing Tanah Pheretima $S p$ selama 60 Hari Pemeliharaan}

Mortalitas cacing tanah Pheretima $s p$ selama 60 hari pemeliharaan dengan menggunakan media dari sekam padi dan feses sapi serta memanfaatkan ampas tahu sebagai pakan tambahan. Asumsi media pada perlakuan pertama P1 adalah 50\% sekam padi $+50 \%$ feses sapi, P2 50\% sekam padi $+45 \%$ feses sapi + ampas tahu $5 \%$, P3 50\% sekam padi $+40 \%$ feses sapi + 
$5 \%$ ampas tahu, P4 50\% sekam padi $+35 \%$ feses sapi $+15 \%$ ampas tahu.

Tingkat pemberian imbangan feses sapi dan pakan tamabahan ampas tahu yang berbeda pada setiap perlakuan dan unit pemeliharaan tidak memperlihatkan pengaruh yang nyata terhadap mortalitas induk. Tidak adanya jumlah mortalitas pada tiap perlakuan $\mathrm{P} 1, \mathrm{P} 2, \mathrm{P} 3$, dan $\mathrm{P} 4$, hal ini disebabkan karena media cocok untuk hidup cacing. Dilihat dari rataan suhu tiap media pada P1; 26,60, P2; 26,68, P3; 26,80 dan P4; 26,40. Menurut Warsana (2009) menyatakan bahwa suhu yang optimum untuk hidup cacing tanah yaitu pada kisaran $21^{\circ} \mathrm{C}-30^{\circ} \mathrm{C}$, suhu yang lebih dari $25^{\circ} \mathrm{C}$ masih baik asalkan adanya naungan dan kelembaban yang optimal. Selain dari faktor suhu, faktor $\mathrm{pH}$ serta kelembaban media sangat mempengaruhi mortalitas pada cacing tanah. Jadi dengan pemberian ampas tahu sebagai pakan campuran cacing tanah Pheretima sp tidak mempengaruhi tingkat mortalitas. Selanjutnya tidak adanya tingkat mortalitas pada setiap perlakuan ini juga dipengaruhi oleh sistem pemeliharaannya yaitu dengan menggunakan rak - rak yang diberi oli pada bagian kaki rak. Penggunaan rak dalam pemeliharaan cacing tanah bertujuan agar mengurangi acaman dari predator seperti semut merah.

\section{Keadaan Suhu, pH dan Kelembaban Selama Pemeliharaan}

Berdasarkan dari hasil pengamatan Suhu, pH serta kelembaban pada media cacaing tanah Pheretima sp selama 60 hari pemeliharaan. Seperti dilihat pada tabel 5.

Tabel 5. Rataan keadaan suhu $\left(\mathrm{C}^{\circ}\right)$, $\mathrm{pH}$, kelembaban(\%) media selama pengamatan

\begin{tabular}{cccc}
\hline Perlakuan & Suhu $\left({ }^{\circ} \mathrm{C}\right)$ & $\mathrm{pH}$ & Kelembaban $(\%)$ \\
\hline P1 & 26,60 & 6,47 & 57,92 \\
P2 & 26,68 & 6,59 & 59,48 \\
P3 & 26,80 & 6,42 & 60,88 \\
P4 & 26,40 & 6,66 & 60,48 \\
\hline Rataan & 26,62 & 6,53 & 59,69 \\
\hline
\end{tabular}

Keterangan : $\mathrm{P} 1=$ sekam padi $50 \%+$ feses sapi $50 \%+(0 \%$ ampas tahu $)$

$\mathrm{P} 2=$ sekam padi $50 \%+$ feses sapi $45 \%+(5 \%$ ampas tahu $)$.

P3 $=$ sekam padi $50 \%+$ feses sapi $40 \%+(10 \%$ ampas tahu $)$.

$\mathrm{P} 4=$ sekam padi $50 \%+$ feses sapi $35 \%+(15 \%$ ampas tahu $)$.

Pada tabel 5 di atas bahwa rataa suhu media selama 60 hari pemeliharaan menunjukan suhu optimumnya yaitu 26,80 dan suhu minimumnya 26,40. Suhu pada penelitian ini masih menunjukan suhu normal. Temperatur tanah yang ideal untuk pertumbuhan cacing tanah antara $15-25^{\circ} \mathrm{C}$
(Sugiyarto et al., 2007). Dengan suhu rata rata 26,62 cacing tanah masih dapat beradaptasi dengan baik. Suhu pada media cacing bisa juga dipengaruhi oleh tiap penyiraman dan pembalikan medianya. Temperatur sangat mempengaruhi aktivitas, metabolisme, pertumbuhan, respirasi dan 
reproduksi cacing tanah. Menurut (Edwards dan Lofty, 1977) menyatakan bahwa perbedaan temperatur sangat mempengaruhi kesuburan cacing tanah.

Rataan $\mathrm{pH}$ pada media hidup cacing tanah dilihat dari tabel 5, memiliki rata rata 65,35. Pada kisaran $\mathrm{pH}$ media tersebut masih dapat di anggap normal untuk pertumbuhan cacing tanah Pheretima $s p$. Menurut Brata (2009) pH optimum untuk pertumbuhan cacing tanah adalah $\mathrm{pH}$ netral yakni antara 6,8-7,2 yang merupakan $\mathrm{pH}$ optimum untuk bakteri bekerja. Kandungan $\mathrm{pH}$ pada media dapat dipengaruhi oleh tingkat pengapuran.

Rataan kelembaban pada media selama penelitian didapat $59,69 \%$ dimana kelembaban optimum yaitu $60,88 \%$ dan kelembaban minimum berkisar 57,92\%. Jadi dalam kisaran kelembaban media yang didapat pada penelitian ini masih tergolong normal. Menurut pendapat Warsana (2009), dimana kelembaban media yang dibutuhkan oleh cacing tanah yaitu 60\%-90\% . Kelembaban media sangat berperan penting dalam menunjang pertumbuhan dan reproduksi pada cacing tanah. Menurut Brata (2009) menyatakan bahwa kondisi media yang kering dapat menurunkan populasi dan kemampuan reproduksi serta pertumbuhan cacing tanah. Kelembaban media cacing tanah sangat dipengaruhi oleh tingkat penyiraman medianya.

\section{KESIMPULAN}

Pemberian pakan tambahan ampas tahu dapat meningkatkan pertambahan bobot badan induk dan bobot badan anak cacing tanah Pheretima sp selama 60 hari pemeliharaan. Berdasarkan dari hasil penelitian ini disaraankan dalam pembudidayaan cacing tanah Pheretima $s p$ yang diberi pakan tambahan ampas tahu, memberikan dampak yang baik terhadap pertambahan bobot badan induk dan bobot badan anak cacing tanah Pheretima sp.

\section{DAFTAR PUSTAKA}

Andriyani, Y. 2006. Pengaruh Pemberian Lumpur Sawit yang Difermentasi dengan Kapang (Trichoderma harzianum) terhadap Produktivitas dan Biomassa Cacing Tanah Pheretima sp. [Skripsi]. Fakultas Pertanian Universitas Bengkulu.

Aziz, A. A, Maulida. 2015. Budidaya Cacing Tanah Unggul Ala Adam Cacing. Penerbit PT AgroMedia. Jakarta Selatan.

Brata, B. 2003. Pertumbuhan dan Perkembangan Kualitas Eksmecat dari Beberapa Spesies Cacing Tanah pada Kondisi Lingkungan yang Berbeda. Disertasi. Program Pascasarjana. Institut Pertanian Bogor. Bogor.

Brata, B. 2009. Cacing Tanah: Faktor Mempengaruhi Pertumbuhan dan Perkembangbiakan. Bogor (ID) : IPB

Press. 
Catalan, G.I. 1981. Earthworms a NewResource of Protein. Philippine Earthworm Center, Philippines.

Edward, C.A., and Lofty, J.R., 1977, Biology of Earthworms, 1-181, 245247, Champman and Hill, New York. 123-142.

Gaddie, R. E and D. E. Douglas, 1977. Earthworm for Ecology and Profit.Vol II. Bookworm Publishing Company Ontario, California.

Haryono. 2003. Pemanfaatan Serbuk Sabut Kelapa dan Ampas Tahu sebagai Media Pakan Cacing Tanah (Lumbricus rubellus). Prosiding Temu Teknis Fungsional Non Peneliti. Bogor. Pusat Penelitian dan Pengembangan Peternakan. 6673 .

Martin, J. P., J. H. Black and Hawthorne. 1981. Earthworm Biology and Production. In: Explore The World of Earthworms. Inset Lecture Hall, UPLB College, Laguna.

Minnich, J. 1977. The Earthworm Book.How To Rise and Use Earthworm For Your Farm. Rodale Press Emmaus. New York. 90-127.

Mursining, 2006. Teknik Pembesaran Ikan Kelemak (Leptobarbus hoeveni Blkr) dengan Pemberian Kombinasi Pakan Berbeda [Skripsi]. Fakultas Perikanan dan Ilmu Kelautan. Universitas Riau. Pekanbaru.
Palungkun, R. 1999. Sukses Beternak Cacing Tanah (Lumbricus rubellus). Penebar Swadaya, Jakarta.

Puspitasari,W.1995. Pengaruh Beberapa Media terhadap Pertumbuhan dan Perkembangbiakan Cacing Tanah ( $E$. Foetida Savigny). Skripsi. Jurusan Biologi. FMIPA. IPB. Bogor. 1-17.

Rukmana. H. R. 1999. Budidaya Cacing Tanah. Penerbit Kanisius (Anggota IKAPI), Yogyakarta Hal $18,28-3$.

Roeslim, D. I., D. S. Nastiti, dan Herman. 2013. Karakter Morfologi dan Pertumbuhan Tiga Jenis Cacing Tanah Lokal Pekanbaru pada dua Macam Media Pertumbuhan. Biosaintifika. 5(1): 1-9.

Sugiyarto, M., E. Efendi, Y. Mahajoeno, Sugito, E. Handayanto, L. Agustina. 2007. Preferensi berbagai jenis makrofauna tanah terhadap sisa bahan organic tanaman pada intensitas cahaya berbeda. Biodiversitas 7(4): 96-100.

Waluyo, D. 1993. Pengaruh Kapur terhadap Perkembangan Tubuh dan Klitelium serta Kadar Protein dan Asam Amino pada Cacing Tanah Esenia foetida savigny. Program Panca Sarjana Institut Pertanian Bogor. Bogor.

Warsana. 2009. Kompos Cacing Tanah (Casting). Tabloid Sinar Tani, Jawa Tengah. 
e-ISSN 2528-7109

p-ISSN 1978-3000

Wiriano. 1985. Pemanfaatan Ampas Tahu Menjadi Berbagai Macam Makanan. Laporan Penelitian. Balai Besar Penelitian dan Pengembangan Industri Hasil Pertanian, Bogor.
Yitnosumarto, S. 1993. Perancangan Percobaan, Analisis dan Interprestasinya. Gramedia Pustaka Umum, Yogyakarta. 